\title{
PENGEMBANGAN LEMBAR KEGIATAN SISWA (LKS) BERBASIS DISCOVERY LEARNING PADA MATERI MENULIS TEKS PROSEDUR SISWA KELAS VII SMP NEGERI 2 BATANG ANAI
}

\author{
Firda Riesha Intannia, Rahayu Fitri, Indriani Nisja \\ Fakultas Bahasa dan Seni \\ Sekolah Tinggi Keguruan dan ilmu Pendidikan \\ Email : rieshaintannia@gmail.com
}

This development research is motivated by the fact that the ability to write procedural texts in the structure and characteristics of language is still low. This is due to the lack of teaching materials. The purpose of this study was to describe the validity and to describe the practicality of the worksheets and to describe the effectiveness of using Student Activity Sheets (LKS) learning to write text procedures based on Discovery Learning for seventh grade students of SMPN 2 Batang Anai. This research is a development research using the 4-DModels development model, which consists of 4 stages, namely define, design, develop, disseminate. However, this research is only up to the develop stage. Data were analyzed using percentage data analysis techniques and processed descriptively. The results of this study are as follows. First, the validity test with the valid category, namely $79.01 \%$ (valid) in terms of content, language, presentation, and graphics. Second, the practicality test in terms of convenience and suitability of time allocations. The teacher practicality test was $86.93 \%$ (very practical) and the student practicality test was $82.63 \%$ (very practical). Third, the effectiveness test seen from the student learning activities $97.61 \%$ (very effective) and student learning outcomes that are $83.88 \%$ (good). It can be concluded that the Student Activity Sheet (LKS) for learning to write a procedure text based on Discovery Learning that is produced is valid, practical, and effective.

\section{Keywords: Student Activity Sheet (LKS), Discovery Learning, Procedure text}

\begin{abstract}
ABSTRAK
Penelitian pengembangan ini dilatarbelakangi bahwa kemampuan menulis teks prosedur dalam struktur dan ciri kebahasaan masih rendah. Hal ini disebabkan karena bahan ajar yang minim. Tujuan dari penelitian ini adalah untuk mendeskripsikan validitas dan mendiskripsikan praktikalitas LKS serta mendeskripsikan efektifitas penggunaan Lembar Kegiatan Siswa (LKS) pembelajaran menulis teks prosedur berbasis Discovery Learning siswa kelas VII SMPN 2 Batang Anai. Penelitian ini merupakan penelitian pengembangan dengan menggunakan model pengembangan 4-DModels, yang terdiri dari 4 tahap, yaitu defenisian (define), perancangan (design), pengembangan (develop), penyebaran (disseminate). Namun penelitian ini hanya sampai tahap pengembangan (develop). Data dianalisis dengan teknik analisis data persentase dan diolah secara deskriptif. Hasil dari penelitian ini adalah sebagai berikut. Pertama, uji validitas dengan kategori valid, yaitu 79,01\% (valid) ditinjau dari segi isi, kebahasaa, penyajian, dan kegrafikan. Kedua, uji praktikalitas ditinjau dari segi kemudahan dan segi kesesuaian alokasi waktu. Uji
\end{abstract}

Program Studi Pendidikan Bahasa dan Sastra Indonesia 
kepraktisan guru, yaitu 86,93\% (sangat praktis) dan uji kepraktisan siswa yaitu 82,63\% (sangat praktis). Ketiga, uji efektivitas dilihat dari aktivitas belajar siswa 97,61\% (sangat efektif) dan hasil belajar siswa yaitu 83,88\% (baik). Dapat disimpulkan Lembar Kegiatan Siswa (LKS) pembelajaran menulis teks prosedur berbasis Discovery Learning yang dihasilkan sudah valid, praktis, dan efektif.

Kata Kunci : Lembar Kegiatan Siswa (LKS), Discovery Learning, Teks prosedur

How to Cite: Firdaus, F. R. I., Fitri, R., \& Nisja, I. (2021). Pengembangan Lembar Kegiatan Siswa (LKS) Berbasis Discovery Learning pada Materi Menulis Teks Prosedur Siswa Kelas VII SMP Negeri 2 Batang Anai. Bahtera Indonesia; Jurnal Penelitian Bahasa Dan Sastra Indonesia , 6(2), 223-235. https://doi.org/10.31943/bi.v6i2.117

DOI: https://doi.org/10.31943/bi.v6i2.117

\section{PENDAHULUAN}

Lembar Kegiatan Siswa (LKS) merupakan sebuah bahan ajar yang digunakan oleh peserta didik dalam proses belajar mengajar, dan sebagai media bagi guru. Lembar Kegiatan Siswa (LKS) tersebut berupa lembaran-lembaran yang berisi ringkasan materi, petunjuk-petunjuk pelaksanaan tugas yang merupakan sebuah latihan dalam menulis bagi peserta didik, yang mengacu pada kompetensi dasar yang harus dicapai oleh guru dan tersusun secara sistematis. Di dalam Lembar Kegiatan Siswa (LKS) juga terdapat tugas individu dan kelompok, sehingga guru lebih mudah mengetahui keberhasilan siswa dalam proses belajar pada materi menulis teks. Beberapa teks yang harus dikuasai pada kelas VII semester I yaitu teks cerita fantasi, teks prosedur, teks laporan hasil observasi, dan teks deskripsi. Menurut Priyatni (2014:87), teks prosedur ialah teks yang memberikan petunjuk untuk melakukan atau menggunakan sesuatu dengan langkah- langkah yang urut. Menulis teks prosedur yaitu sebuah kegiatan yang mengasah pola pikir peserta didik dalam mengembangkan tata cara membuat kerajinan tangan dan membuat makanan yang dituangkan dalam bentuk tulisan sesuai dengan struktur dan ciri kebahasaannya. Pengembangan menulis teks prosedur juga harus memperhatikan struktur dan unsur kebahasaannya.

Berdasarkan hasil wawancara pada tanggal 13 Oktober 2020 dengan salah seorang guru bahasa Indonesia, Rosnida, S.Pd, yang mengajar di kelas VII SMP N 2 Batang Anai bahwa kemampuan menulis teks prosedur peserta didik masih rendah. Hal ini disebabkan karena kurangnya kosa kata, tanda baca, pengembangan kalimat, dan motivasi peserta didik untuk menulis. Selain itu, juga dinyatakan bahwa dalam pembelajaran menulis teks prosedur ada beberapa masalah yang dialami guru, yaitu sebagai berikut. Pertama, media yang dipergunakan guru ketika mengajar yaitu papan tulis dan beberapa gambar yang diperlihatkan, sehingga siswa mudah bosan. 
Kedua, kurangnya materi teks prosedur karena materi hanya dari buku teks yang tersedia di sekolah saja. Ketiga, guru lebih sering menggunakan model ceramah dan diskusi saja. Keempat, guru belum pernah menggunakan LKS Kurikulum 2013. Pada saat Kurikulum KTSP guru menggunakan LKS, tetapi ketika sekolah tersebut menggunakan Kurikulum 2013 guru dan peserta didik hanya menggunakan bahan ajar buku cetak.

Sesuai dengan hasil wawancara yang dilakukan dengan mewawancari tiga orang siswa kelas VII SMPN 2 Batang Anai pada tanggal 15 Oktober 2020, diperoleh beberapa permasalahan dalam menulis teks prosedur. Beberapa permasalahan yang terjadi pada siswa dalam proses belajar mengajar teks prosedur adalah sebagai berikut. Pertama, siswa kurang memahami struktur dan ciri kebahasaan yang terdapat dalam teks prosedur. Kedua, siswa kurang paham tentang materi teks prosedur karena hanya mengandalkan buku teks dan penjelasan dari guru. Ketiga, siswa sulit untuk menemukan topik dalam membuat teks prosedur.

Berdasarkan masalah di atas, maka dilakukan penelitian ini dengan mengembangkan sebuah LKS yang sesuai dengan kurikulum 2013. Guru harus bisa menciptakan bahan ajar yang lebih menarik minat siswa untuk belajar seperti Lembar Kegiatan Siswa (LKS) yang penyajiannya berbeda dengan buku teks. Perbedaan LKS tersebut terletak pada bentuk penyajian yang menarik, berwarna, bergambar, dan materi yang digunakan berbasis Discovery Learning. Model Discovery Learning lebih mengutamakan proses belajar mengajar yang menunjang keaktifan siswa dalam memecahakan masalah, menentukan ide yang akan ditulis siswa, sehingga siswa mampu mengembangkan sebuah kalimat. Menurut Hamdani (2011: 184), Discovery (penemuan) adalah proses mental ketika siswa mengasimilasikan suatu konsep atau suatu prinsip. Proses mental tersebut misalnya mengamati, menjelaskan, mengelompokkan, membuat kesimpulan, dan sebagainya. Menurut Priansa (2017: 258), menyatakan bahwa Discovery Learning merupakan model pembelajaran yang mengatur cara peserta didik memperoleh pengetahuan yang belum diketahuinya dengan cara yang penuh kemandirian. Dengan dikembangkan LKS berbasis Discovery Learning ini dapat menimbulkan minat peserta didik dalam belajar dan lebih paham serta mudah mengembangkan topik atau ide. Tujuan dari pengembangan LKS berbasis Discovery Learning pada materi menulis teks prosedur yang valid dan praktis serta efektif bagi siswa kelas VII SMP Negeri 2 Batang Anai.

Penelitian yang pernah dilakukan oleh Tiara (2014) dalam penelitian yang berjudul "Pengembangan Lembar Kegiatan Siswa (LKS) Bahasa Indonesia Berbasis Discovery Learning Berbantuan Media Gambar Berseri pada Materi Menulis Teks Cerita Fantasi Siswa Kelas VII SMPN 6 Kota Solok". Selanjutnya penelitian dari Putri (2014) dalam penelitian yang berjudul "Pengembangan Lembar Kegiatan Siswa (LKS) Bahasa Indonesia Berbasis Inkuiri pada Materi Menulis Teks Prosedur Siswa Kelas VII SMP Muhammadiyah 6 Padang." 
Kemudian penelitian yang dilakukan oleh Meta (2014) dalam penelitian ini yang berjudul "Pengembangan Lembar Kegiatan Siswa (LKS) Bahasa Indonesia Berbasis Inkuiri Pada Materi Menuliskan Kembali Teks Biografi Siswa Kelas X SMK Negeri 1 Pantai Cermin." Berdasarkan hasil penelitiannya, dapat disimpulkan beberapa hal yaitu. Dalam hasil belajar digunakan untuk mengetahui data yang diperlukan untuk menentukan persentase keberhasilan siswa setelah belajar menggunakan LKS berbasis Inkuiri materi teks prosedur. Hasil belajar ini meliputih ranah psikomotor, yang digunakan dalam tes kerja. Tesnya dilaksanakan pada bagian akhir pembelajaran untuk mengetahui tingkat kemampuan belajar siswa dalam menulis teks prosedur.

Penelitian yang akan dilakukan ini berbeda dengan penelitian yang lainnya. Penelitian ini difokuskan pada

\section{METODE}

Penelitian pengembangan Lembar Kerja Siswa (LKS) berbasis Discovery Learning ini menggunakan rancangan model yang dikemukakan oleh Thiagarajan, dkk (1974: 6-8). Model pengembangan, yaitu (1), pendefinisian (Define), (2) perancangan (Design), (3) pengembangan (Develop), dan (4) penyebaran (Desseminate). Namun, penelitian ini hanya sampai pada tahap pengembangan (development) dengan menguji kevaliditas dan uji praktikalitas serta uji efektivitas Lembar Kegiatan Siswa (LKS). Subjek uji coba penelitian ini langsung di lapangan, yaitu di SMP N 2 Batang Anai. Uji coba lapangan ini dilakukan terhadap 30 orang siswa kelas VII SMP N 2 Batang Anai setelah melakukan pemilihan uji
Pengembangan Lembar Kegiatan Siswa (LKS) Berbasis Discovery Learning pada Materi Menulis Teks Prosedur Siswa Kelas VII SMPN 02 Batang Anai. Perbedaan penelitian ini dengan penelitian lainnya adalah terlihat pada subjek penelitian, objek penelitian, penggunaan strategi, media dan waktu penelitian. sedangkah persamaan penelitian ini dengan penelitian lainnya adalah sama-sama meneliti pengembangan Lembar Kegiatan Siswa (LKS). Berdasarkan uraian di atas, maka penting untuk melakukan penelitian dalam menciptakan atau mengembangkan bahan ajar berupa Lembar Kegiatan Siswa (LKS) berbasis Discovery Learning pada materi menulis teks prosedur, yang diwujudkan dalam judul "Pengembangan Lembar Kegiatan Siswa (LKS) Berbasis Discovery Learning pada Materi Menulis Teks Prosedur Siswa Kelas VII SMPN 2 Batang Anai."

coba produk. Jenis data yang dihasilkan dari uji coba berupa penilaian terhadap produk yang diujicobakan dan terhimpun melalui instrumen evaluasi Lembar Kegiatan Siswa (LKS). Jenis data dalam penelitian ini berupa data kuantitatif. Instrumen yang digunakan dalam pengumpulan data pada penelitian ini adalah angket, lembar observasi, dan tes unjuk kerja. Teknik analisis data yang digunakan adalah teknik analisis data deskriptif. Teknik analisis deskriptif dilakukan dengan menggunakan statistik deskriptif. Statistik deskriptif ini adalah statistik yang digunakan untuk menganalisis data dengan cara mendeskripsikan atau menggambarkan data yang telah terkumpul sebagaimana adanya tanpa bermaksud membuat kesimpulan yang berlaku untuk umum atau generalisasi. Analisis data hasil 
penelitian dilakukan untuk mengetahui validitas, kepraktisan, dan efektivitas lembar Kegiatan Siswa (LKS) yang telah dibuat.

\section{HASIL PENELITIAN}

Proses pengembangan LKS pembelajaran berbasis Discovery Learning menggunakan model 4-D. Pengembangan penelitian ini dilakukan terdiri dari tiga tahap, yaitu tahap pendefinisian (define), perancangan (design), dan pengembangan (develop). Pada tahap pendefenisian dilakukan dalam lima tahap, yaitu langkah dengan melakukan analisis awal-akhir, analisis siwa, analisis tugas, analisis konsep, dan kurikulum. Untuk analisis awal-akhir didapatkan bahwasanya belum tersedianya lks pembelajaran berbasis Discovery Learning karena di sekolah tersebut hanya menggunakan buku teks guru dan siswa yang telah disediakan sehingga masalah awal yang ditemukan di SMPN 2 Batang Anai adalah rendahnya kemampuan menulis teks prosedur siswa kelas VII. Oleh karena itu perlu dikembangkan LKS pembelajaran menulis teks prosedur berbasis Discovery Learning siswa kelas VII. Kemudian hasil analisis siswa yang dilihat dari segi karakteristiknya siswa yang sekolah di SMPN 2 Batang Anai adalah anak-anak yang masih berusia antara 12-14. Usia tersebut siswa sudah mampu memahami hal-hal yang bersifat imajinatif. Selanjutnya untuk analisis tugas yang dilakukan terhadap hasil tugas siswa, yaitu terdapat kelemahan pada bagian struktur dan ciri kebahasaan teks prosedur. Masih banyak siswa kelas VII yang belum memahami materi tentang struktur dan ciri kebahasaan teks prosedur. Hal ini tentu berdampak pada hasil tugas siswa yang kurang mampu dalam menentukan struktur dan ciri kebahasaan teks prosedur. Langkah selanjutnya yaitu analisis konsep dimana indikator pembelajaran yang telah diuraikan tersebut, maka dapat ditentukan konsepkonsep utama materi menulis teks prosedur. Konsep utama materi menulis teks prosedur terdiri dari: 1) Pengertian teks prosedur, 2) Struktur teks prosedur, 3) Ciri kebahasaan teks prosedur, 4) Contoh teks prosedur. Langkah terakhir dari tahap pendefenisian ini yaitu analisis kurikulum yang dapat dilihat pada tabel berikut.

Tabel 1. Rumusan Indikator Pembelajaran Menulis dalam LKS Pembelajaran

\begin{tabular}{llll}
\hline No & \multicolumn{1}{c}{ Indikator } & \multicolumn{2}{c}{ Tujuan Pembelajaran } \\
\hline 1. & Merencanakan penulisan teks prosedur & $\begin{array}{l}\text { Siswa mampu merencanakan penulisan } \\
\text { teks prosedur. }\end{array}$ \\
\hline 2. & $\begin{array}{l}\text { Menulis teks prosedur dengan memperhatikan } \\
\text { pilihan kata, kelengkapan struktur, dan kaidah } \\
\text { penggunaan kata, kalimat, atau tanda baca/ ejaan }\end{array}$ & $\begin{array}{l}\text { Siswa mampu menulis teks prosedur } \\
\text { dengan memperhatikan pilijan kata, } \\
\text { penggunan kata kalimat/tanda baca/ ejaan }\end{array}$
\end{tabular}

Sumber : Data Diolah, 2020

Program Studi Pendidikan Bahasa dan Sastra Indonesia 
Tahap selanjutnya pada penelitian ini yaitu tahap perancangan (Design). Pada tahap ini dilakukan perancangan Lembar Kegiatan Siswa (LKS) pembelajaran menulis teks prosedur berbasis Discovery Learning siswa kelas VII SMPN 2 Batang Anai. Lembar Kegiatan Siswa (LKS) pembelajaran dirancang dengan berbasis Discovery Learning dengan tujuan agar siswa lebih termotivasi untuk belajar. Kemudian pada tahap ini mempunyai beberapa karakteristik mengenai design LKS yang terdiri dari judul/sampul depan, kata pengantar dan daftar isi, petunjuk belajar, kompetensi inti dan kompentensi dasar, informasi pendukung, tugas atau langkah kerja, dan terakhir penilaian. Mengenai judul/sampul depan 1KS dirancang dengan menambahkan gambar dan warna yang menarik sperti warna biru dan putih sehingga dapat menumbuhkan semangat belajar siswa dengan menggunakan LKS. Berikut hasil rancangan judul/ sampul depan dari Lembar Kegiatan Siswa (LKS)

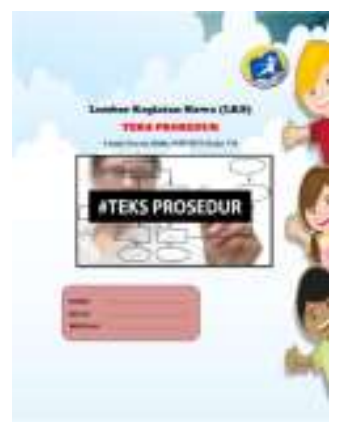

\section{Gambar 1. Judul dan Sampul Lembar Kegiatan Siswa (LKS) Pembelajaran}

Selanjutnya untuk kata pengantar dan daftar isi Lembar Kegiatan Siswa (LKS) pembelajaran biasanya. Lembar Kegiatan Siswa (LKS) pembelajaran berbasis Discovery Learning ini juga dilengkapi dengan kata pengantar dan daftar isi. Kata pengantar berisikan ucapan rasa syukur dan ucapan terima kasih kepada semua pihak yang telah membantu serta memotivasi dalam penyelesaian Lembar Kegiatan Siswa (LKS) pembelajaran ini. Daftar isi berisikan topik-topik yang akan dibahas dalam Lembar Kegiatan Siswa (LKS) pembelajaran. Daftar isi digunakan untuk memudahkan siswa atau pembaca mengetahui halaman yang diinginkan. Bagian dari tahap perancangan juga ada petunjuk belajar yang terdiri dari dari petunjuk umum, petunjuk membaca LKS, dan petunjuk belajar. Petunjuk umum berisi gambaran isi LKS secara umum, petunjuk membaca LKS berisi bagaimana langkah-langkah atau cara membaca LKS, dan petunjuk belajar berisi bagaimana cara belajar menggunakan LKS. Kompetensi inti dan kompetensi dasar juga telah sesuai dengan analisis konsep yang tertera pada tabel 1 untuk memberikan penjelasan singkat dan ruang lingkup dari Lembar Kegiatan Siswa (LKS) pembelajaran yang dikembangkan. Kemudian bagian informasi pendukung pada LKS berbasis discovery learning terdiri dari informasi yang berbentuk bagan. Kemudian bagian yang terdapat pada LKS berbasis Discovery Learning ini yaitu adanya tugas/langkah kerja kerena pada bagian ini yang terpenting pada LKS. Hal inilah yang menjadi pembeda LKS dengan bahan ajar lainnya, yaitu lebih menekankan adanya tugas-tugas yang bertujuan untuk mengukur kemampuan siswa terhadap materi yang diajarkan, khususnya materi menulis teks prosedur. Tugas yang terdapat pada LKS ini terdiri dari tiga bagian, yaitu uji kompetensi 1,2 , dan 3 . Uji kompetensi 1 berupa soal objektif, uji kompetensi 2 berupa soal esai, dan uji kompetensi 3 berupa tes unjuk kerja. Agar lebih jelas, perhatikan gambar di bawah ini. 
BAHTERA INDONESIA:

Jurnal Penelitian Pendidikan Bahasa dan Sastra Indonesia
ISSN 2541-3252

Vol. 6, No. 2 Sep. 2021
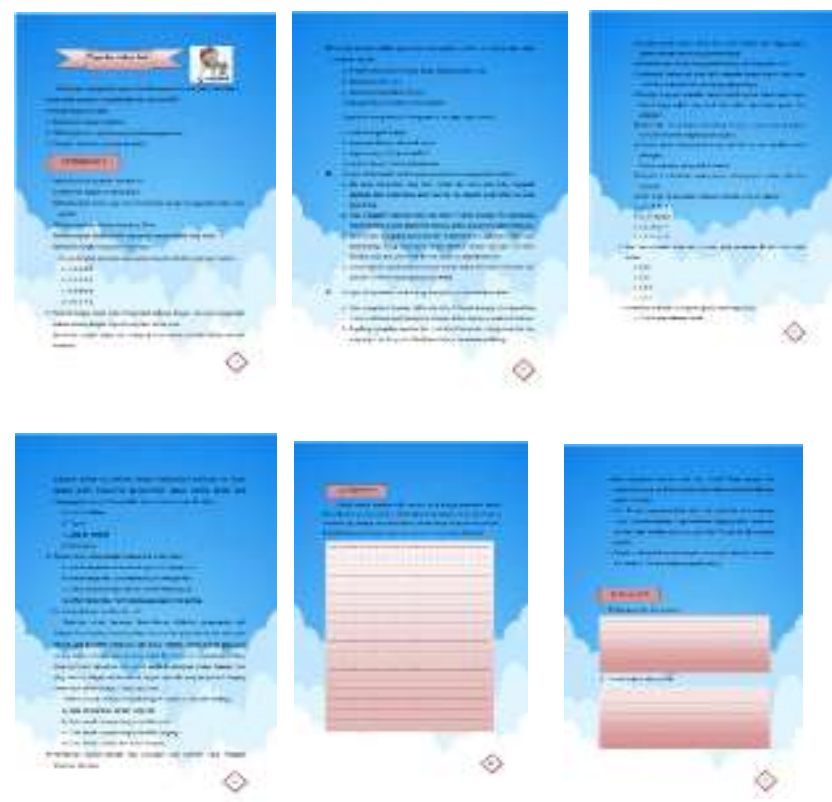

\section{Gambar 2. Tugas yang terdapat dalam Lembar Kegiatan Siswa (LKS)}

Terakhir bagian penilaian yang dirancang untuk kegiatan yang dilakukan oleh siswa dihargai dengan pemberian nilai. Pada proses penilaian, guru memiliki patokan tertentu terhadap tugas yang dikerjakan oleh siswa.

Setelah dilakukan tahap perancangan dilanjutkan dengan tahap pengembangan. Tahap pengembangan yang dilakukan meliputi validasi Lembar Kegiatan Siswa (LKS) pembelajaran dan uji coba produk. Validitas Lembar Kegiatan Siswa (LKS) pembelajaran dapat diketahui setelah divalidasi oleh validator, yaitu dosen STKIP PGRI Sumatera Barat. Setelah Lembar Kegiatan Siswa (LKS) pembelajaran divalidasi, selanjutnya Lembar Kegiatan
Siswa (LKS) pembelajaran diujicobakan kepada siswa. Hal ini sesuai dengan pendapat Thiagarajan, ddk (1974: 8) bahwa tahap pengembangan meliputi validasi perangkat oleh pakar dan uji coba terbatas dengan siswa yang sesungguhnya. Untuk validasi Lembar Kegiatan Siswa (LKS) telah dirancang divalidasi oleh 2 validator ahli yang sesuai dengan bidang kajinnya, yaitu Ricci Gemarni Tatalia, M.Pd dan Rina Sartika, M.Pd. Setelah memberikan penilaian, validator ahli juga memberikan saran-saran untuk pengembangan produk lebih lanjut. Saransaran yang diberikan oleh validator yaitu dosen bahasa Indonesia pada tabel tersebut dijadikan sebagai bahan pertimbangan dalam pelaksanaan revisi Lembar Kegiatan Siswa (LKS) pembelajaran yang telah dikembangkan. Berdasarkan hasil analisis yang telah dilakukan, dapat diperoleh hasil validasi Lembar Kegiatan Siswa (LKS) pembelajaran secara umum memperoleh skor rata-rata $79,01 \%$ dengan kategori valid. Penjabaran terhadap aspek yang dinilai di antaranya sebagai berikut. Aspek kelayakan isi diperoleh rata-rata persentase $81,25 \%$ dengan kategori valid. Aspek kelayakan bahasa diperoleh rata-rata persentase $81,25 \%$ dengan kategori sangat valid. Aspek kelayakan penyajian mendapatkan rata-rata persentase 78,57\% dengan kategori valid. Aspek kegrafikaan mendapatkan rata-rata persentase $75 \%$ dengan kategori valid. Agar lebih jelas perhatikan tabel berikut ini.

Tabel 2. Hasil Validasi Ahli

\begin{tabular}{ccccc}
\hline No & Aspek Penyajian & Skor yang Diperoleh & Nilai Validasi & Kategori \\
\hline 1. & Aspek kelayakan isi & 80 & 81,25 & Sangat Valid \\
\hline
\end{tabular}




\begin{tabular}{clccc}
\hline 2. & $\begin{array}{l}\text { Aspek kelayakan } \\
\text { bahasa }\end{array}$ & 32 & 81,25 & Sangat Valid \\
\hline 3. & $\begin{array}{l}\text { Aspek kelayakan } \\
\text { penyajian }\end{array}$ & 56 & 78,57 & Valid \\
\hline 4. & Aspek kegrafikan & 20 & 75 & Valid \\
\hline \multicolumn{2}{c}{ Jumlah } & $\mathbf{1 8 8}$ & $\mathbf{7 9 , 0 1}$ & Valid \\
\hline
\end{tabular}

Sumber : Data Diolah, 2020

Berdasarkan hasil validasi Lembar Kegiatan Siswa (LKS) pembelajaran pada tabel tersebut, disimpulkan bahwa secara umum Lembar Kegiatan Siswa (LKS) pembelajaran yang sudah dikembangkan dengan kategori sangat valid. Hal ini berarti Lembar Kegiatan Siswa (LKS) pembelajaran yang telah dikembangkan dapat diujicobakan pada siswa untuk digunakan dalam proses belajar mengajar. Setelah Lembar Kegiatan Siswa (LKS) berbasis discovery learning divalidasi oleh validator selanjutnya dilakukan uji coba produk dengan menguji kepraktikalitas dan uji efektifitas penggunaan LKS. Pelaksanaan uji coba dilakukan terhadap 30 orang siswa dan 1 guru kelas VII SMPN 2 Batang Anai. Pada pelaksanaan uji coba diperoleh data uji praktikalitas dan uji efektivitas. Uji praktikalitas dihasilkan dari angket yang sudah diisi oleh guru dan siswa. Hasil praktikalitas diperoleh dari hasil respon guru yaitu Ibu Rosnida R, S.Pd sebagai praktisi terhadap praktikalitas Lembar Kegiatan Siswa (LKS) pembelajaran berbasis Discovery Learning bahwasanya praktikalitas Lembar Kegiatan Siswa (LKS) bagi guru memperoleh skor rata-rata $85,79 \%$ dengan kategori sangat praktis. Penjabaran praktikalitas Lembar Kegiatan Siswa (LKS) pembelajaran bagi guru sebagai berikut. Aspek kemudahan dalam penggunaan memperoleh skor rata-rata $86,36 \%$ dengan kategori sangat praktis. Aspek kesesuaian dengan waktu memperoleh skor rata-rata 87,5\% dengan kategori sangat praktis. Agar lebih jelas perhatikan tabel di bawah ini.

Tabel 3. Hasil Kepraktisan Guru Secara Umum

\begin{tabular}{llccc}
\hline No & Aspek Penyajian & $\begin{array}{l}\text { Skor yang } \\
\text { Diperoleh }\end{array}$ & Nilai Validasi & Kategori \\
\hline 1. & $\begin{array}{l}\text { Aspek kemudahan } \\
\text { dalam penggunaan }\end{array}$ & 38 & 86,36 & Sangat Praktis \\
\hline 2. & $\begin{array}{l}\text { Aspek kesesuaian } \\
\text { dengan waktu }\end{array}$ & 7 & 87,5 & Sangat Praktis \\
\hline & Jumlah & $\mathbf{4 5}$ & $\mathbf{8 6 , 9 3}$ & Sangat Praktis \\
\hline
\end{tabular}

Sumber : Data Diolah, 2020

Berdasarkan tabel di atas, dapat diketahui bahwa penilaian terhadap aspek praktikalitas Lembar Kegiatan Siswa (LKS) pembelajaran bagi guru berkategori praktis. Hal itu dapat dilihat dari aspek kemudahan dalam penggunaan dan aspek kesesuaian dengan waktu. Penilaian aspek kemudahan dalam penggunaan dan aspek kesesuaian dengan waktu secara umum berkategori praktis. Sedangkan uji kepraktikalitas bagi siswa mendapatkan hasil praktikalitas Lembar Kegiatan Siswa (LKS) pembelajaran 
bagi siswa secara umum memperoleh skor rata-rata $82,63 \%$ dengan kategori sangat praktis. Penjabaran praktikalitas Lembar Kegiatan Siswa (LKS) pembelajaran bagi siswa sebagai berikut. Aspek kemudahan dalam penggunaan memperoleh skor rata- rata $81,94 \%$ dengan kategori sangat praktis. Aspek kesesuaian dengan waktu memperoleh skor rata-rata $83,33 \%$ dengan kategori sangat praktis. Agar lebih jelas perhatikan tabel berikut ini.

Tabel 4. Kepraktisan Lembar Kegiatan Siswa (LKS) Pembelajaran Bagi Siswa

\begin{tabular}{llcc}
\hline No & \multicolumn{1}{c}{ Aspek Penyajian } & Persentase & Kategori \\
\hline $\begin{array}{l}1 . \\
\text { Aspek kemudahan dalam } \\
\text { penggunaan }\end{array}$ & 81,94 & Sangat Praktis \\
\hline $\begin{array}{l}\text { 2. } \\
\text { Aspek kesesuaian dengan } \\
\text { waktu }\end{array}$ & 83,33 & Sangat Praktis \\
\hline \multicolumn{2}{c}{ Jumlah } & $\mathbf{8 2 , 6 3}$ & Sangat Praktis \\
\hline
\end{tabular}

Sumber : Data Diolah, 2020

Berdasarkan tabel di atas, dapat diketahui bahwa penilaian terhadap praktikalitas Lembar Kegiatan Siswa (LKS) bagi siswa yang dikembangkan secara umum berkategori sangat praktis. Hal ini dapat dilihat dari penilaian aspek kemudahan dalam penggunaan dan aspek kesesuaian dengan waktu. Penilaian aspek kemudahan dalam penggunaan secara umum berkategori sangat praktis. Uji coba produk selanjutnya itu dilakukan uji efektivitas yang dilihat dari hasil aktivitas siswa selama belajar menggunakan LKS dan nilai yang diperoleh siswa ketika belajar dengan menggunakan lembar kegiatan siswa. Berdasarkan pengamatan yang telah dilakukan maka aktivitas siswa dalam menggunakan LKS ini sangat berhasil sehingga mampu membangkitkan semangat belajar siswa. Sedangkan untuk nilai yang diperoleh diketahui bahwa tingkat ketuntasan secara umum yaitu 83,33 sudah berkategori baik. Namun, ada 5 orang siswa yang nilai hasil belajarnya berkategori cukup, berkategori sedang 2 orang, dan 23 orang siswa yang berkategori baik, dan baik sekali dengan ratarata 83,88 . Sebagian siswa yang berkategori cukup nilainya dibawah Kriteria Ketuntasan Minimum (KKM) dan berkategori sedang juga dibawah Kriteria Ketuntasan Minimum (KKM) 71 yang ditetapkan oleh sekolah, maka nilainya belum mencapai Kriteria Ketuntasan Minimum (KKM). Namun, tetap saja secara umum nilai hasil belajar siswa sudah tergolong baik, dengan begitu Lembar Kegiatan Siswa (LKS) pembelajaran yang dikembangkan sudah efektivitas.

\section{Lembar Kegiatan Siswa (LKS)} pembelajaran berbasis Discovery Learning dirancang untuk bahan belajar mandiri pada materi menulis teks prosedur. Lembar Kegiatan Siswa (LKS) pembelajaran ini telah diujicobakan pada 30 orang siswa kelas VII SMPN 2 Batang Anai. Berdasarkan hasil analisis data uji coba produk, Lembar Kegiatan Siswa (LKS) pembelajaran ang dikembangkan ini telah berkategori valid, praktis, dan efektif. Oleh sebab itu, Lembar Kegiatan Siswa (LKS) pembelajaran ini sudah dapat digunakan pada pembelajaran 
bahasa Indonesia khususnya pada materi menulis teks prosedur. Sebelum Lembar Kegiatan Siswa (LKS) pembelajaran diberikan kepada siswa untuk pembelajaran, terlebih dahulu Lembar Kegiatan Siswa (LKS) pembelajaran harus valid, praktis, dan efektif. Mengenai validitas LKS pembelajaran itu sebelum diujicobakan itu harus divalidasi sesuai dengan Emzir (2013:273) yang menyatakan bahwa validasi merupakan proses penilaian rancangan produk yang dilakukan dengan memberikan penilaian berdasarkan pemikiran yang rasional. Lembar Kegiatan Siswa (LKS) pembelajaran menulis teks prosedur berbasis Discovery Learning untuk siswa kelas VII SMPN 2 Batang Anai yang dirancang tergolong valid. Lembar Kegiatan Siswa (LKS) pembelajaran yang dikembangkan telah dapat diujicobakan kepada siswa untuk melihat kepraktisan dan kefektifan.

Praktikalitas Lembar Kegiatan Siswa LKS pembelajaran yang dikembangkan dapat diketahui dari pelaksanaan uji coba. Uji coba lapangan dilakukan setelah Lembar Kegiatan Siswa (LKS) pembelajaran divalidasi oleh validator ahli. Hal ini sejalan dengan pendapat Zainuddin, dkk (2012:68) menyatakan bahwa kepraktisan Lembar Kegiatan Siswa (LKS) pembelajaran dapat dinilai dari isi menarik, tampilan menarik, penjelasan mudah dimengerti, kalimat mudah dipahami, serta teknik yang dapat membangkitkan minat belajar siswa dan gambar mudah dipahami. Pada pelaksanaan uji coba diperlukan masukan dari teman sejawat atau tim ahli dan juga masukan dari peserta didik untuk mengetahui persepsi mereka tentang Lembar Kegiatan Siswa (LKS) pembelajaran yang digunakan. Data praktikalitas diperoleh dari praktikalitas
Lembar Kegiatan Siswa (LKS) pembelajaran bagi guru dan siswa. Dilihat dari segi kepraktisan penggunaan oleh guru Lembar Kegiatan Siswa (LKS) pembelajaran menulis teks prosedur berbasis Discovery Learning untuk siswa kelas VII SMP yang dikembangkan dapat digunakan oleh guru dalam proses belajar mengajar karena mudah digunakan dan sesuai dengan waktu yang telah ditetapkan di dalam kurikulum 2013 revisi. Sedangkan jika dilihat dari kepraktisan penggunaan oleh siswa, Lembar Kegiatan Siswa (LKS) pembelajaran berbasis Discovery Learning untuk siswa kelas VII SMP yang dikembangkan dapat digunakan oleh siswa di dalam pembelajaran. Hal ini dikarenakan Lembar Kegiatan Siswa (LKS) pembelajaran mudah dilaksanakan dan sesuai dengan waktu yang telah ditetapkan di dalam kurikulum 2013 revisi. Selanjutnya mengenai efektivitas penggunaan lembar kegiatan siswa ini dilihat dari dari aktivitas siswa dan hasil belajarnya.

Berdasarakan pengamatan yang dilakukan oleh guru sebagai observer dapat disimpulkan bahwa aktivitas belajar siswa dengan menggunakan Lembar Kegiatan Siswa (LKS) pembelajaran berbasis Discovery Learning pada materi menulis teks prosedur siswa kelas VII SMPN 2 Batang Anai yang dikembangkan tergolong sangat berhasil. Hal itu terlihat dari keaktifan siswa dalam belajar. Menurut pengamatan observer, keberhasilan aktivitas siswa selama belajar disebabkan oleh Lembar Kegiatan Siswa (LKS) pembelajaran yang dikembangkan berbasis Discovery Learning . Sedangkan untuk hasil belajar dari siswa itu bahwa secara klasikal belum semua siswa dinyatakan tuntas. Hal ini dapat dilihat dari nilai yang diperoleh, 7 orang siswa berada di 
bawah rata-rata nilai ketuntasan minimum yang telah ditentukan sekolah. Jika ditinjau secara individu dari 30 orang siswa yang ikut tes menulis teks prosedur belajar dengan menggunakan Lembar Kegiatan Siswa (LKS) pembelajaran, 23 orang siswa mendapat nilai di atas KKM (71) dan 7 orang siswa yang tidak mencapai KKM. Kemudian setelah ditelaah hasil analisis terhadap penilaian terhadap teks prosedur siswa disimpulkan bahwa kesalahan terbanyak yang dilakukan siswa adalah pada bagian struktur dan ciri kebahasaan yang digunakan dalam teks prosedur.

Pada penelitian ini adanya revisi dari produk yang didapatkan pada saat uji validitas, uji kepraktikalitas dan efektivitas penggunaan LKS berbasis Discovery Learning. Selain memberikan penilaian, validator juga memberikan saran-saran. Saran-saran yang diberikan validator untuk merevisi Lembar Kegiatan Siswa (LKS) pembelajaran adalah memperbaiki Lembar Kegiatan Siswa (LKS) pembelajaran. Perbaikan mulai dari cover, kata pengantar, daftar isi, langkah-langkah dan lainnya. Agar lebih jelasnya perhatikan gambar berikut.

\section{Sebelum Revisi}

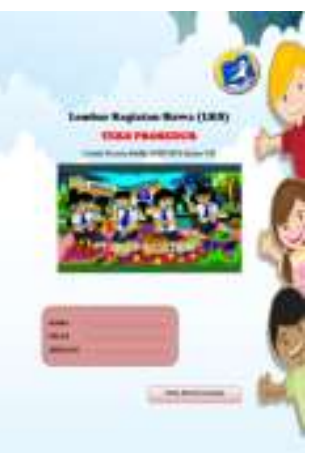

\section{Sesudah Revisi}

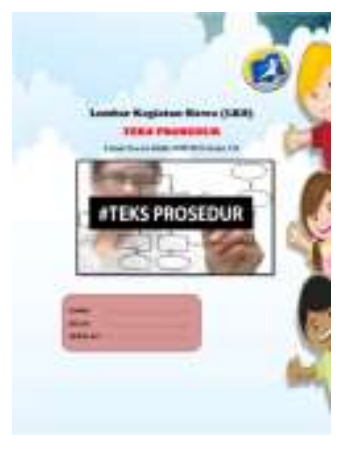

Segi kegrafikan pada cover tidak banyak diubah, cover Lembar Kegiatan Siswa (LKS) yang telah divalidasi oleh validator mendapatkan saran untuk menambahkan nama penulis. Cover Lembar Kegiatan Siswa (LKS) juga harus diperbaiki desain pada sampul depannya. Segi kegrafikan tidak hanya di bagian cover saja, tetapi juga ditambah di bagian-bagian lain yang bisa ditambah dengan gambar. Beberapa hal juga harus diperbaiki pada segi kelayakan isi, di bagian kompetensi yang akan dicapai. Hasil validasi oleh validator, tujuan tidak sesuai dengan indikator yang telah ada. Maka penulis memperbaiki tujuan yang akan dicapai pada kompetensi yang dicapai. Informasi pendukung sebelum revisi dengan sesudah revisi berbeda, karena sesuai saran validator terhadap isi dari informasi pendukung tidak jelas menurut siapa teori yang dicantumkan. Dengan adanya saran dari validasi, maka informasi pendukung dicantumkan referensi yang digunakan dalam teori. Agar lebih jelasnya perhatikan gambar berikut.

\section{Gambar 3. Cover Lembar Kegiatan Siswa (LKS)}




\section{Sebelum Revisi}

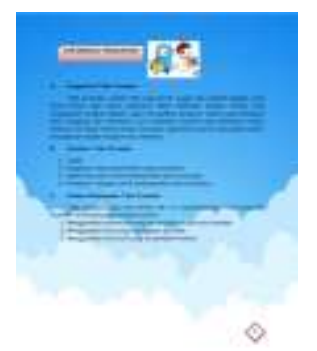

Sesudah Revisi

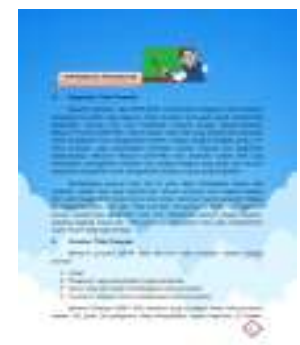

Gambar 4. Informasu Pendukung

\section{SIMPULAN}

Berdasarkan hasil penelitian yang telah dilakukan dapat disimpulkan bahwa LKS pembelajaran menulis teks prosedur berbasis Discovery Learning yang dikembangkan telah memenuhi kriteria valid, praktis, dan efektif. Validitas Lembar Kegiatan Siswa (LKS) pembelajaran yang dikembangkan dapat dilihat dari keempat aspek yang telah diuji, yaitu aspek kelayakan isi, aspek kelayakan bahasa, aspek kelayakan penyajian dan aspek kegrafikan. Hasil validitas dari segi aspek kelayakan isi, yaitu $81,25 \%$ dengan kategori sangat valid. Hasil validitas dari segi aspek kelayakan bahasa, yaitu $81,25 \%$ dengan kategori sangat valid. Hasil validitas dari segi aspek kelayakan penyajian, yaitu $78,57 \%$ dengan kategori sangat valid. Hasil validitas dari segi aspek kegrafikaan, yaitu 75\% dengan kategori valid. Berdasarkan keempat aspek tersebut, maka hasil validitas LKS pembelajaran ini secara umum 79,01\% dengan kategori valid.

Praktikalitas Lembar Kegiatan Siswa (LKS) pembelajaran yang dikembangkan ini dapat dilihat berdasarkan dua aspek, yaitu aspek kemudahan dalam penggunaan dan aspek kesesuaian dengan waktu. Praktikalitas Lembar Kegiatan Siswa (LKS) pembelajaran ini dilakukan oleh guru dan siswa. Pertama, hasil paraktikalitas guru dari aspek kemudahan dalam penggunaan Lembar Kegiatan Siswa (LKS) pembelajaran, yaitu 86,36\% dengan kategori sangat praktis. Hasil praktikalitas dari segi kesesuaian dengan waktu, yaitu $87,5 \%$ dengan kategori sangat praktis. Berdasarkan kedua aspek tersebut, maka hasil praktikalitas oleh guru secara umum, yaitu 86,93\% dengan kategori sangat praktis. Kedua, hasil paraktikalitas dari aspek kemudahan dalam penggunaan Lembar Kegiatan Siswa (LKS) pembelajaran, yaitu $81,94 \%$ dengan kategori sangat praktis. Hasil praktikalitas dari segi kesesuain dengan waktu, yaitu 83,33\% dengan kategori sangat praktis. Berdasarkan kedua aspek tersebut, maka hasil praktikalitas oleh guru dan siswa secara umum, yaitu 82,63\% dengan kategori sangat praktis. Efektivitas Lembar Kegiatan Siswa (LKS) pembelajaran yang dikembangkan dilihat dari aktivitas siswa dan hasil belajar siswa. Hasil efektivitas dari segi aktivitas siswa, yaitu 97,61\% dengan kategori sangat berhasil. Hasil efektivitas dari hasil belajar siswa yaitu, 76,66\% dengan kategori baik.

Tampilan Lembar Kegiatan Siswa (LKS) pembelajaran ini dirancang dengan berbasis Discovery Learning dapat memotivasi dan meningkatkan minat belajar siswa, sehingga dapat membantu dan memperlancar proses pembelajaran menulis teks prosedur. Hal ini sesuai dengan tujuan pembelajaran yang akan dicapai, yaitu meningkatkan kemampuan menulis teks prosedur.

\section{DAFTAR RUJUKAN}

Arikunto, Suharsimi dan Cepi Safruddin Jabar. 2008. Evaluasi Program Pendidikan. Jakarta: Bumi Aksara.

Dalman. 2016. Keterampilan Menulis. Jakarta: Raja Grafindo Persada.

D Darmawan, D Wahyudin. 2018. Model Pembelajaran Di Sekolah. Bandung: PT Remaja Rosdakarya

Depdiknas. 2008. Panduan Pengembangan Bahan Ajar. Jakarta: Direktorat Jenderal Pendidikan Dasar dan 
Menengah Direktorat Pembinaan Sekolah Menengah Atas.

Ekawati, E.B. Devitta dan Siti Isnatun M. 2017. Bahasa Indonesia SMP/MTs Kelas VII. Jakarta: Yudhistira

Hamdani. 2011. Strategi Belajar Mengajar. Bandung : Pustaka Setia.

Hosnan. 2014. Pendekatan Santifik dan Kontekstual dalam Pembelajaran. Jakarta: G halia Indonesia

Kusumaningsih, Dewi dkk. 2013. Terampil Berbahasa Indonesia. Sukoharjo: Penerbit Andi

Majid, Abdul. 2013. Strategi Pembelajaran. Bandung: PT Remaja Rosdakarya.

Nurgiyantoro, Burhan. 2001. Penilaian dalam Pengajaran Bahasa dan Sastra: Edisi Ketiga. Yogyakarta: PT BPFE.

Prastowo, Andi. 2011. Panduan Kreatif Membuat Bahan Ajar Inovatif. Yogjakarta: DIVA Press.

Priansa, Juni Donni. 2017. Pengembangan Strategi \& Model Pembelajaran Inovatif, Kreatif, dan, Prestatif dalam Memahami Peserta Didik. Bandung. CV Pustaka Setia

Priyatni, Endah Tri. (2014). Desain Pembelajaran Bahasa Indonesia dalam Kurikulum 2013. Jakarta: PT Bumi Aksara

Purwanto. 2011. Evaluasi Hasil Belajar. Yogyakarta: Pustaka Pelajar

Riduwan. 2012. Skala Pengukuran Variabelvariabel Penelitian. Bandung: Alfabeta.

Rosidi, Imron. 2013. Menulis Siapa Takut. Yogyakarta: KANISIUS

Sudijono, Anas. 2004. Pengantar Statistik Pendidikan. Jakarta: Raja Grafindo Persada.
Sugono, Dendi. 2008. Kamus Besar Bahasa Indonesia. Jakarta. PT. Gramedia Pustaka Utama

Tabroni, Roni. 2007. Melejitkan Potensi: mengasah kreativitas menulis artikel. Bandung: NUASA

Tarigan, Henry Guntur. 2008. Menulis sebagai Suatu Keterampilan Berbahasa. Bandung: Penerbit Angkasa.

Thiagarajan, S; Semmel, D.S; \& Semmel, M.I. 1974. Instructional Development for Training Teachers of Exceptional Children: A Sourcebook. Indiana: Indiana University.

Widiasworo, Erwin. 2017. Strategi dan Metode Mengajar Siswa Di Luar Kelas (Outdoor Learning) Secara Aktif, Kreatif, Inspiratif, dan Komunikatif. Yogyakarta. Ar-Ruzz Media. 